\title{
The dissolving of marriages in Ezra 9-10 and Nehemiah 13 revisited
}

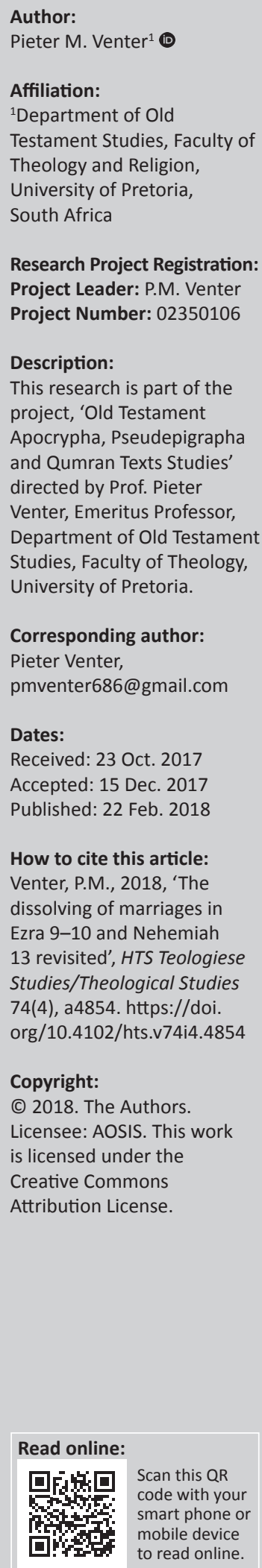

The 'harsh' decision in Ezra 10:1-44 and Nehemiah 13:23-31 to terminate marriages with 'foreign' women falls strange on modern ears. This article reads these sections against the background of identity formation in Ezra-Nehemiah. It is proposed that these two passages should be studied on more than just one level. It states that synchronic, literary-redactional and socio-historical methods are to be combined in an effort to better understand why marriages were dissolved in Ezra and Nehemiah.

\section{Introduction}

The Hebrew scriptures refer to both inclusive as well as exclusive communities. In the books of Ruth and Jonah, people from outside the group of the traditional Israel are included. In EzraNehemiah certain people are excluded. This debarment of people from the fold of Israel is explicitly found in Ezra 10:1-44 and Nehemiah 13:23-31. In both cases marriages were dissolved because Israelite men were married to 'foreign women' from the neighbouring people.

This article visits these passages (again) in an effort to understand this phenomenon. The thesis proposed here is that these texts can no longer be read on just one level, using only one type of method. Investigation should at least be done in three phases.

Firstly, these sections are to be interpreted in the literary context of the Masoretic text of Ezra and Nehemiah. This calls for a synchronic contextual reading of the present text.

Secondly, the text is to be read as the final outcome of a process of growth. Earlier renderings of the final composition were edited and rewritten to form the present text. There are intertextual links to not only other texts in the Old Testament, but also indications in the Ezra-Nehemiah text itself of using and reusing earlier phases of the text itself. The final Masoretic edition is studied as a multilayered text that was compiled in different stages. This calls for a synchronic-diachronic type of analysis.

Thirdly, a diachronic reading should follow. These passages come from a specific socio-historical world with its own set of unique circumstances. The text is therefore also to be read in the context of a reconstructed contemporary social world.

Following these three steps will lead to a much more nuanced understanding of this strange (for us, anyhow) dissolving of marriages in Ezra-Nehemiah.

\section{A synchronic strategy to understand Ezra 10:1-44 and Nehemiah 13:23-31}

Eskenazi $(1988,2008)$ is well known for her synchronic narrative analysis of Ezra-Nehemiah. She reads the two books as one ${ }^{1}$ continuing narrative. Although 'dissenting voices' or 'multiple voices' (Eskenazi 2008:316) can be heard in the document, there is a particular unity among this disunity. Eskenazi (1988:74) views these books as 'a literary artifact in which diverse sources combine meaningfully to express particular ideologies'. Eskenazi (2008:322) is still of the opinion, 20 years after her first publication in 1988, that 'the formation of community' is the central idea in EzraNehemiah.

Eskenazi's (1988) synchronic analysis parses the Ezra-Nehemiah narrative into three parts: The first part (Ezr 1:1-4) states the potential building of a 'house for God'. The second part (Ezr 1:5 to

1.There is a long-standing discussion on the unity of Ezra and Nehemiah; see Vanderkam (1992), Boda and Redditt (2008), Giffone (2014:49-50), Jonker (2016), Sarah Japhet (1994) and Williamson (1987) for a discussion of this problem. 
Neh 7:72) narrates the actualization and completion of this command. The third section (Neh 7:73-13:31) deals with the feast held at the successful completion of the project. The issue of non-Jewish wives in Ezra 9:1-2 belongs to the second movement. It was one of the problems that was to be solved to form a holy community. Not only the priests and Levites were to be holy, but all of the people. That required the drastic step of divorcing from non-Judean women.

Sending the women away in Nehemiah's time (13:23-31) is part of the third section. Eskenazi (1988:96-97) names this third part 'Success (Objective Reached): The Community Celebrates the Completion of the House of God According to the Torah'. In Nehemiah 11:1-13:31 the community translates the instruction of the Torah 'into commitment and action' (Eskenazi 1988:101). The dismissal of women here is to be read as the practical execution of God's command to be holy.

Throntveit's (1992) synchronic reading points out three successive narrative scenes of return: return under the guidance of Zerubbabel (Ezr 1-7), return under the leadership of Ezra (Ezr 7:27-10:44) and the return under Nehemiah (Neh 1:1-7:3). The identification of men who had to divorce their foreign wives in Ezra falls under the events of Ezra's return $(7: 27-10: 44)$. It is part of the cultic actions he took to rebuild the religious society. The issue of foreign wives in Nehemiah 13:23-30 belongs to the section of Nehemiah's return. In the Nehemiah section, there are three scenes in which the same pattern is followed: reference to a specific time, specifics of a gathering, followed by an occasion where the Torah is read and applied ('application'; cf. Throntveit 1992:7). Each of these scenes 'culminates in the people's response to the law and focuses our attention on the renewal of the congregation ...' (Throntveit 1992:7). The 'restoration community' (Throntveit 1992:100) took several remedial actions to avoid repeating the errors of the past, one of them being divorcing foreign women to whom some of them were married. In both cases, the sending away of foreign women is seen as action taken to renew the congregation.

Van Wyk's (2001:1254) 'close analysis' of the Ezra-Nehemiah text indicates that the dissolving should be read in terms of 'the central issue of access to the community of returned exiles' (Van Wyk 2001:1254). The dissolving of the mixed marriages in Ezra 7-10 was aimed at nothing else than to exclude the local population from the exilic community (cf. Van Wyk 2001:1259). Although 'primarily religious' (Van Wyk 2001:1260) this measure was materialistically motivated to protect the returnees' prosperity from the local inhabitants. This brings Van Wyk (2001:1263) to the conclusion that the real issue in these conflicts was 'access to the community of returned exiles'.

Clauss' (2011) study of the final text uses a 'synchronic literary methodology' (Clauss 2011:110). Ezra-Nehemiah narrates 'an overall process of identity formation' (Clauss 2011:109). Within this overarching identity theme there are three interrelated themes: return from exile, building of the temple and the conflicts experienced inter alia in the form of mixed marriages. Read within the interrelated nexus of these three themes, the intermarriage crisis is to be understood in terms of the rebuilding of the temple and the nature of the builders, who separated themselves from the uncleanness of the nations. Temple and purity 'hermeneutically organize the perception of this conflict' (Clauss 2011:116) of intermarriage.

Clauss (2011:129-130) is of the opinion that 'Israel is not affected by mixed marriages as an ethnical entity, if understood in biologistic, racist sense, but as religious one'. Because Israel is 'defined cultic-religiously' (Clauss 2011:130), their holiness is connected to the Lord's holiness and their relationship with him. Their identity is formed by their devotion to God and the close association with temple and city. This is of direct relevance to the issue of mixed marriages. The 'obligation to endogamy is an ethical requirement due to Israel's essential trait - the exclusively close relation to YHWH' (Clauss 2011:130). Mixed marriages are here 'a means to illustrate the sacral status of the city and the people's awareness of an immediate proximity to $\mathrm{YHWH}$ in their conduct of life' (Clauss 2011:131).

To summarise: the synchronic analyses of Ezra-Nehemiah above read these passages in terms of a semantic constructed composition with a central theme or built around interrelated subthemes. Holiness as an integral part of a new restoration community seems to be generally accepted as that main theme. Eskenazi (1988) reads Ezra 10:1-44 as part of the process for the community to become a holy people. Nehemiah 13:23-31 depicts the execution of God's command to be holy. Throntveit (1992) understands the dissolving of the marriages in Ezra 10:6-44 as part of Ezra's cultic actions to rebuild the religious society. Throntveit sees the sending away of the foreign women in Nehemiah 11:1-13:31 as a remedial action taken by the restoration community to be holy. Van Wyk (2001) interprets Ezra 7-10 as control of the local population, preventing them from becoming part of this holy community of returned exiles. Clauss' (2011) synchronic literary study relates the marriage problem to the returnees' identity formation within the parameters of the temple and the city. A new community is formed. Their identity is defined in terms of holiness. The mixed marriages pollute the holy status.

It is not sufficient to study these texts on a synchronic level only. Firstly, there are repetitions and quotations in the text, indicating a literary process of growth that lead to the final text. The text should be studied against this background as well. Secondly, a community is a social phenomenon. Synchronic analysis indicates this as a holy community. What this really intends should also be studied using social scientific criticism. We now turn to these two fields of study.

\section{Reading Ezra 10:1-44 and Nehemiah 13:23-31 as parts of a multilayered text}

The obvious use of other biblical texts in Ezra-Nehemiah, like Deuteronomy 7:1-4 and Deuteronomy 23:3-5, asks for 
further inquiry. The studies of Fishbane (1985), Boyarin (1990) and Fisk (2001) on inner biblical exegetical strategies are well known. Fisk (2001) sees the eventual forming of the Bible as a historical process. Fisk (2001:33) focuses on the area of the 'social-historical context of the tradents' and the 'range of hermeneutical relationships obtaining between the biblical text and the new composition' (Fisk 2001:33). He wanted to investigate whether the secondary composition was created to explicate, transform or even overturn the older text (the traditum). This can be called intertextual research. Bautsch (2007:25) defines intertextuality as 'a matter of texts, later texts, and the scholarly perception of a connection between them'.

In intertextual research there are two foci: social context and the hermeneutics of interpreting an existing text. There are at least two aspects of intertextuality when Ezra-Nehemiah is read. On the one hand, a biblical text can use older texts within the context of its own provenance. There is superfluous proof in Ezra-Nehemiah that older texts (in whatever form - final, or still in the process of becoming part of the present final canonical text) were used. However, repetitions (e.g. twice-repeated actions of dissolving of marriages in Ezr 10:1-44 and Neh 13:23-31) show that there are layers or redactional phases still visible in the final text. There is therefore both a diachronic aspect (a history behind and in the text itself) as well as a synchronic aspect (the hermeneutical way older literature was incorporated in a final structured text). This brings us to a diachronic-synchronic type of analysis.

Bautsch (2007:35) summarises the work of various scholars using the method of intertextual studies, working 'closely with the most determined data in the text, namely, words and expressions'. Bautsch refers to Fishbane's intertextual analysis of Ezra 9:1-10:19 as an example. There was no indication in the Torah for the expulsion of foreign spouses. Intermarriage was even tolerated (Gn 41:45; Nm 12:1-8; Rt 1:4; $2 \mathrm{Sm} \mathrm{3:3).} \mathrm{To} \mathrm{ratify} \mathrm{the} \mathrm{dissolving} \mathrm{of} \mathrm{marriages} \mathrm{with}$ foreign wives, the author of Ezra 10:3-5 used Deuteronomy 7:1-3 to develop a legal argument. Intertextual exegesis was used here to widen older Pentateuchal stipulations (the traditum) to legalize the ideological actions of a newer time (traditio). In this process, other sources no longer available could have been used.

There could have been different stages in the application and the reapplication of this older material. Eskenazi (2008:316) refers to an 'editorial or compositional process'. A text can be created using either the combination of 'free standing documents' (Eskenazi 2008:316) or a 'more gradual, incremental process in which scribal activities responded in a continuous fashion to issues internal to the text and those external' (Eskenazi 2008:317).

Grabbe (1998) studied the intertextual relations within EzraNehemiah itself. Grabbe (1998:175) finds the similarity between Ezra 9-10 and Nehemiah 9-10 'more than coincidental'. The situation of intermarriage is found in both (cf. Neh 10:28). In both, the people gather and repent. In both cases a prayer is found. In both, a separation from the 'foreigners' occurs. In both passages, a list records those who agreed to abide by the ruling. However, the lists are different. Nehemiah 10:1-30 lists those who signed a contract to abide by the pledge they made, whilst Ezra 10:20-43 is a list of those who had 'sinned' by their marriages. This brings Grabbe (1998:176) to the conclusion 'that one is only a version of the other'. He proposes that Ezra 9-10 is a later expansion of Nehemiah 9-10.

With regard to this compositional process, Williamson (1985) identifies different stages in this redactional activity. According to Williamson, an Ezra Memoir and a Nehemiah Memoir were inter alia used and extended to form the two sections of Ezra 7:1 to Nehemiah 11:20 and the section of 12:27 to 13:31. Finally, Ezra 1-6 was added to these two separate and eventually combined sections to complete the writing. Williamson understands this redactional process within its historical context. In Nehemiah 13 it is depicted that a diminishing of sacrifices caused a retrogation in the services rendered at the temple. Trying to preserve 'the distinctive purity of the Jewish religion' (Williamson 1985), Nehemiah took certain measures regarding the Sabbath and marriages. The purpose of Ezra was to set down the requirement for membership of the returned exilic group. This was to be done in light of the economic power exerted by those who remained behind, called the people of the land'. The returnees used the Mosaic law as their 'constitutional foundation' (Williamson 1985). This law unfortunately did not provide explicit rules for their situation. Following the principles of the law, the decision was made to dissolve certain marriages. In both cases of Ezra and Nehemiah, the dissolving of marriages to outsider women was to preserve the purity of the Jewish religion.

Scholars differ on the (theoretical) order of this process. In some instances, the order of the biblical material (Ezra followed by Nehemiah) is followed. In other cases, the order is switched around to set Nehemiah (or parts of it) as the older material. Whichever order is followed, the 'newer' material is always interpreted in light of the theoretical 'older' material. This, of course, can present different readings of the same text and is the weak point of this theoretical type of approach.

Raik Heckl (2016) understands the material of Ezra-Nehemiah as a multilayered text. He analyses these layers as representing different phases in the compositional growth of this diversified composition. Heckl (2016:410) calls the EzraNehemiah composition a Programmschrift [prospectus]. This program was intended to indicate the return from the exile, the temple in Jerusalem and the Jerusalem exposition of the Torah as the sole and exclusive matrix (cf. Heckl 2016:410) for post-exilic Israel. It is the end product of a process of Fortschreibung [continuous writing] (Heckl 2016:14) in which existing texts (meta-texts) were transformed in a new situation. Heckl uses a literary critical method to study EzraNehemiah. He also uses communication theory to enable 
him to understand the communication situation reflected in these texts. This situation reflects the discourses that took place, as well as the socio-historical situation in which this continuing writing took place (cf. Heckl 2016:14).

A text therefore reflects both older texts, their reworking, and the socio-historic circumstances under which this communicative process ended in a final text. Information from archaeology, surrounding cultures and parallel texts enables one to draw up a communicative frame (cf. Heckl 2016:21) in which the text was formed. The tool of intertextuality is used to reconstruct this framework.

Heckl distinguishes three aspects of intertextuality. The first form of intertextuality is that of aktualisierenden Rezeption [actualising reception] (Heckl 2016:23). The original wording of texts from Deutero-Isaiah, Jeremiah and the Torah (not necessarily in the present final Masoretic form) are recognisable in the composition of Ezra-Nehemiah. Heckl identifies three main sources used for the Ezra-Nehemiah narrative. They are lists in Ezra 2 and Nehemiah 7, an Aramaic temple construction chronicle (cf. Heckl 2016:23) and a Nehemiah biographical narrative. Heckl focuses on the way these texts were used to produce the final composition.

A second form of intertextuality is the literary use of religious and quasi-canonical texts. This form is explicitly found in Ezra-Nehemiah. An example of this form is the use of the Edict of Cyrus and the Artaxerxes Edict.

A third form of intertextuality is that of contrasting reference, where a text is read from a perspective different to that of the original text (cf. Heckl 2016:25). Examples of this are found in Ezra 1-6, where the Torah is expounded from a total different contemporary angle.

Therefore, studying Ezra-Nehemiah as a multilayered text, Heckl reads the dissolving of marriages in Ezra 9-10 and Nehemiah 13 against the background of a literary development over time, specifically that of the Hellenistic time. In both passages, the Community Rule of Deuteronomy 23:3-5 plays a role (cf. Heckl 2016:294). In Ezra 9 various concepts found in the Pentateuch are used. It explores the older prohibition on intermarrying with Hittites, Girgashites, Amorites, Canaanites, Perizzites, Hivites and Jebusites (Dt 7:1-4). These concepts are now read in a priestly context and linked to the notions of purity and transgressing God's law. Mirroring contemporary ideas found in Manetho's Aigyptiaka and the work of Hekataikos from Abdera, mixed marriages are depicted as a threat to Judaic identity. This, unfortunately, accentuates the problem indicated above. If the text reflects a Persian era, rather than a Hellenistic era (when, e.g., Manetho's and Hekataikos' ideas were not yet available) would the outcome regarding contemporary identity be exactly the same?

The heading under which Heckl discusses Ezra 9-10 is quite informative: Avoidance of mixing and demarcation from other people as reaction to the developments in Hellenism and its application to the separation from the Samarians (cf. Heckl 2016:294). Heckl (2016:294) views this move as an innovation constituted by biblical texts and concepts that were nicht mit den Konzepten des verwendeten Texte der Tora identisch [that were not necessarily identical to the concepts of the texts used from the Torah] (Heckl 2016:297). Older texts were contextualized in a dynamic Hellenistic age to counteract the tendencies of the era. Ezra 9-10 presents eine frühe halachische Antwort [an early halachic answer] (my emphasis on frühe) (Heckl 2016:297) to the challenges presented by Hellenism. This new Exogamietabu [intermarriage taboo] (Heckl 2016:298) was in the first instance an ideologisches wenn man so will restauratives - Konzept [ideological, if you wish, restorative, concept] (Heckl 2016:298). The problem did not exist in Ezra 1-6, but after that some recontextualising took place and the composition of the population changed and a new problem arose of the preservation of the holy seed.

The list of male divorcees in Ezra 10:18-44 agrees with the lists in Ezra 2 and Nehemiah 7. They were in fact only a percentage of those who returned to the land. Against the general mixing of people in the context of the larger empire, measures were now taken for Identitätssicherung in Jerusalem als Ideal [securing identity as ideology in Jerusalem] (Heckl 2016:300). Although the relationship with the Samarians was friendly up till this stage, growing enmity lead to viewing them negatively (cf. Heckl 2016:300). Heckl even thinks that it was not the Samarians as such but actually other nations that presented the problem of finding their own identity. Jerusalem identity was bolstered by the rigorous measures of dissolving marriages with foreign wives - and it was not with the Samarian women as such (cf. Heckl 2016:301). The repeated references to Cyrus' command and the building of the temple indicates that the provenance of the Ezra history was an inneriüdischen bzw. innerisrealitischen Konkurrenzsituation [inner Judaic, respectively, inner Israelitic, contesting situation] (Heckl 2016:300). It was ideologically driven, as it was not only a matter of the right temple for God but also the correct exposition of the traditional Torah.

Heckl (2016:361) sees the Nehemiah document as parallel to the Ezra document, but he calls it ein eigenständiges Werk [independent work]. ${ }^{2}$ When comparing the parallel lists in Ezra 2 and Nehemiah 7 with Nehemiah 10, he proposes an interval of 20 to 40 years between the Ezra and Nehemiah sections. The context changed and a transformation can be seen from Nehemiah 9 on. The Torah is now applied to a different situation. Similar to the way the Ezra document recontextualised its temple construction narrative source, the Nehemiah documentmadean umfängliche Rekontextualisierung der Nehemiaerzählung [extensive recontextualising of the Nehemiah narrative] (Heckl 2016:361).

Analogous to Ezra 9-10, a penitential prayer is used in Nehemiah 9 as well, also leading to the problem of mixed marriages. Ezra's prayer (Ezr 9) was followed by an application of the law. The same pattern is followed in

2.This touches upon the decades-long debate already indicated on the continuity or discontinuity, unity or disunity between Ezra and Nehemiah. 
Nehemiah. His prayer forms a hinge between the Nehemiah narrative and the following employment of the Torah to include support of the temple, keeping of the Sabbath and the solving of the mixed marriage problem. While the marriage problem was used as single theme in Ezra, it no longer stands on its own in Nehemiah. Bussgebet und Bundesschluss [penitential prayer and covenant making] (Heckl 2016:320) formed the centre of the Nehemiah narrative source. 'All Israel' now becomes those under the leaders of Jerusalem who were willing to renew the covenant with God.

Different from Ezra, a distinction is now made between those who are part of this covenant and those other Judeans who are not (Heckl 2016:334). We are rather dealing with a Teilgruppe [sectional group] (Heckl 2016:370). The earlier generalization of separation found in Ezra and the older Nehemiah narrative is now developed further in terms of purity, especially against the Samarians, as indication of the identity of the Judeans.

It also becomes clear that an inner Judean conflict is at stake. Heckl states that the conclusion in Nehemiah 13:4-31 is concerned with eine innerjüdische bzw. innerisraelitische Auseinanderseztung [an inner Judaic, respectively, inner Israelitic exposition] (Heckl 2016:346). In the final Nehemiah document, there are innerisraelitischen Gegner [inner Israelite adversaries] (Heckl 2016:370). In Heckl's view, this indicates an ongoing rivalry with the authorities in Samaria and the temple built upon Gerizim. While it was not racial at the start, the idea of mixed marriages as held by a separated group in Jerusalem now became a grundsätzliches Konzept [fundamental notion] (Heckl 2016:383) transferred from people in general pertinently now to inhabitants of Samaria. The Samarians are seen as a mixed people, while Judah and Jerusalem are seen as unvermischten Volkes [unmixed (pure) people] (Heckl 2016:383).

Another diachronic study comes from Pakkala (2011). He is in agreement with Heckl's view on the direction of literary growth. He sees the final form of Ezra-Nehemiah as the outcome of a 'complicated redaction history' (2011:79). It is a layered text formed by means of redactional activity during the Second Temple period, reflecting the ideas of the Persian and Hellenistic periods. Pakkala (2011:79) traces the editorial phases in the development of the themes of intermarriage and group identity in the Ezra tradition (found in Ezr 7-10 and Neh 8). He identifies three original sources used in EzraNehemiah. Ezra 10 is the oldest source. Ezra 9 expanded on it. Nehemiah 13 is the youngest part, built upon Ezra 9-10 and the 'Nehemiah memoir'. In the oldest Ezra source, intermarriage was already linked to the Law of Moses. Although not the central idea yet, later editors made the issue of intermarriage into the central idea, serving as example of what would happen if Moses' law were not obeyed. In Ezra's prayer (Ezr 9) it is 'raised to a more prominent role' (Pakkala 2011:83). Quoting from guidelines regarding Israel's separation from others in Deuteronomy $(7: 3 ; 11: 8-10 ; 18: 9-14$; 23:7), intermarriage becomes the cause of the exile in this prayer. The Deuteronomistic conceptions are now reformulated in priestly terms to describe intermarriage as contamination of the holy seed. In the third stage of Nehemiah 13, intermarriage becomes one of the main threats to the 'integrity and identity of the Jewish community' (Pakkala 2011:84). The returnees are viewed as the only real Israel. The problem is what to do with those who stayed behind during the exile and married foreign women. The exile is now the central theme in Judean identity. The people of the land were seen to be impure and threaten the real Israel as separate group. To become a member of this returned faction, men had to send their foreign wives away. This movement in identity classification was written by a 'small priestly elite' (Pakkala 2011:88), who acted as leaders during that time.

Frevel and Conczorowki represent the opposite order of Nehemiah-Ezra. Frevel and Conczorowki (2011:15) investigate whether there was any 'literary development of the rejection of exogamy'. They study the diachronic relation between Ezra 9-10 and Nehemiah 13:23-29. According to them, these texts on mixed marriages come from the era between the late Persian period and the early Hellenistic time. The texts represent the discourses on marriage of that time. They obviously choose a more neutral historic background and sidestep Heckl's more nuanced Hellenistic theory. Like Williamson and Grabbe above, they postulate the 'literary dependence' (Frevel \& Conczorowki 2011:32) of Ezra 9-10 on Nehemiah 13:23-29. The reference to Ashdodite women in Nehemiah 13:23 indicates 'the economic rise in Persian Period II' (Frevel \& Conczorowki 2011:33). This was approximately the first half of the fourth century BCE Ezra 9-10 is younger and can be understood as elucidation and as exacerbation of Nehemiah 13 (cf. Frevel \& Conczorowki 2011:32).

In the older Nehemiah section, a literary process of growth can already be identified. Although there are not any direct allusions to any anti-exogamous texts of cultic or religious nature in Nehemiah 6:18, a development of the mixed marriage problem is already signalled here (cf. Frevel \& Conczorowki 2011:22). Nehemiah 13:23-27 uses the prohibitions in Exodus 23:31-32, 34:15-16 and Deuteronomy 7:3-5. Verses 23-27 signal 'a Torah discourse which has already a midrashic tendency' (Frevel \& Conczorowki 2011:26). These verses establish religiously based boundaries based on Israel's covenant with God. Verses 28-29 are cultically based. Mixed marriages are implicitly understood here as defiling the ranks of cultic personnel. The problem of intermarriage is linked here to the family of the high priest and focuses on the election of the priests. Nehemiah 13:30 links the religious and cultic of the previous two sections in 13:23-27 and 13:28-29 with each other. The purification of the people and the proper organization of cultic personnel are now set in parallel.

Ezra 9-10 develops the ideas of Nehemiah 13 in a new direction. The idea of 'holy seed' is introduced here. The post-exilic community have to be holy and focus their lives on the temple. Leviticus 18 's purity paradigm is linked to the Deuteronomistic prohibition against intermarriage. As holy people living in the presence of the sanctuary, Israel should 
not intermingle with the impure people of the land. Marrying foreign women would extend 'impurity to Israel as a whole' (Frevel \& Conczorowki 2011:27). While Nehemiah restricts intermarriage to the family of the high priest, Ezra combines Deuteronomistic laws and priestly rules to propagate an 'idea of an extended holiness' (Frevel \& Conczorowki 2011:28). According to Frevel and Conczorowki (2011:28), this 'development depends on a changed self-perception of the Israelite community'.

Frevel and Conczorowki (2011:32) give several literary reasons for their point of view that Ezra developed Nehemiah 13 into 'a unified anti-exogamous position'. Nehemiah 13:26 refers to Solomon's history of marrying foreign women in 1 Kings 11:1-8. This was disapproved in terms of Deuteronomistic covenant theology. Ezra 9-10 'deals with the danger mixed marriages generate for the relation between Israel and its God in a much more differentiated way' (Frevel \& Conczorowki 2011:31). Mixed marriages express the unfaithfulness of the holy seed against their God. While Nehemiah 13 does not use any purity terminology and distinguishes between marriages of priests and those of lay people, Ezra sees mixed marriages as a direct offence against the holy seed that endangers their existence in the land. In Ezra 9-10, 'aspects of religious deviance, covenant, monotheism, genealogy and purity are brought together in a complementary manner' (Frevel \& Conczorowki 2011:32).

Turning to the probable background, Frevel and Conczorowki theorise that exogamy seems to have been a burning issue during early Hellenistic times. The community had to redefine their identity under new circumstances. The reference to the out-group is stylised in terms of the older biblical tradition of the surrounding nations in Deuteronomy 7:1-3 to articulate the identity of the in-group. These nations are not concrete entities anymore, but their names are used allegorically to define the borders set to the identity of the Jerusalem-centred post-exilic community (cf. Frevel \& Conczorowki 2011:33). This reapplication of an older concept to reject intermarriage was later taken up in post-biblical tradition. The exclusivist position of Ezra 9-10 is continued in extra-biblical material such as Jubilees, the Aramaic Levi Document and 4QMMT. There emerged 'a kind of religious orthodoxy in contrast to the construction of an ethnic identity which had been more important in earlier texts' (Frevel \& Conczorowki 2011:34).

Laird (2016:345) states that Ezra-Nehemiah is 'an ensemble of texts composed by various authors at different times and knitted together by later editors'. The final text comprises three sections: the Nehemiah memoir-based section, the Ezra memoir (Ezra 7-10, Nehemiah 8) and the narrative of Ezra 1-6 added to the previous sections during the last decades of Persian rule (410-333 BCE). In the Nehemiah section (written in $445 \mathrm{BCE}$ and thereafter), setting down boundaries is important but it does not yet specify the exact identity of the members of the cohesive community. The Ezra memoir comes from 'an established literary elite associated with the exilic community' (Laird 2016:346). The Torah (as interpreted at that time) and the exilic history became the conceptual criterion for membership in their time. Each of these sections contributes to a 'developing definition of the community' (Laird 2016:346).

In this synchronic-diachronic section we pointed out intertextuality as one of the main tools. Not only were older texts used, but previous editions of Ezra-Nehemiah were also utilised to refine the position of identity. Some scholars theorize that the composition was formed in the same order as it is found in the Bible. Heckl and Williams follow the order of the biblical text. Others, like Frevel and Conczorowki, and Laird, see Ezra as the last addition to previous sections in Nehemiah. They are all in agreement that a refining of identity took place. An elitist use was made of the Torah, closing down the ranks of the returnees to exclude those who did not qualify for membership. Intermarriage to women outside the group threatened this exclusive body of returned exiles.

Heckl (2016) studies Ezra-Nehemiah within the sociohistoric communicative frame of a dynamic Hellenistic age. The developing composition used biblical concepts from the Torah to formulate an ideological identity for a sectional small group of returnees within a larger domain of foreign power. The dissolving of marriages was intended to support the group's identity in an inner Yehudi contesting situation in Yehud. Ezra and Nehemiah represent two different historical situations between 20 and 40 years from each other. While the dissolving of marriages was a single theme in Ezra, it became part of a renewed covenant in Nehemiah encompassing other measures as well. Identity became a much more exclusive fundamental notion pertinently aimed at excluding the mixed population of Samaria from the pure people of Jerusalem.

Pakkala (2011) also points out identity as the main issue. In the older Ezra 10 intermarriage and group identity was linked to the Torah. Based on Ezra, the priestly elite in Nehemiah 13 made intermarriage a central theme depicted as a threat to the exile returnees - the only real Judeans.

Frevel and Conczorowki (2011) change the traditional direction of the book's order and follow Williamson's (1985) idea that Ezra 9-10 expanded Nehemiah 13. The purification and organization of the priestly personnel in Nehemiah is extended in Ezra to the 'holy seed', prohibiting intermarriage between the Jerusalem-centred post-exilic community and other people. Laird (2016) places the expansion of Nehemiah, first by Ezra 7-10 and then by Ezra 1-6 in the last decades of Persian rule. Each phase of the redactional history represents a developing definition of the community's identity. The dissolving of marriages to foreign women indicated the exact identity of the members of the cohesive exilic community.

Not only reconstructed history but also hints at the type of community indicated in Ezra-Nehemiah played a role in the studies above. This calls for investigation of the social context in which the narrated events and the building up of a 
narration of them took place. We therefore turn to social scientific criticism and its results.

\section{Reading Ezra 10:1-44 and Nehemiah 13:23-31 against a multidimensional socio-historic context}

\section{Ezra-Nehemiah in relation to Chronicles}

Fisk (2001:33) points our attention to the area of the 'socialhistorical context of the tradents'. Laird (2016:37) iterates Johnson's idea that the study of literature is only meaningful when it is related to the 'objective field of social relation'. A text is part of the social context from which it comes. The responsible authors of Ezra-Nehemiah stood in conversation with the social world of postexilic Yehud. Diachronical analysis of this background is needed to understand the dissolving of marriages in Ezra-Nehemiah. Jonker's 2016 study of Chronicles is quite helpful in this regard. Jonker (2016:64) proposes 'an interdisciplinary multidimensional approach' in his study of Chronicles. He presents a model of integrating social studies when studying biblical texts. Jonker's model can be applied to the study of the background of Ezra 9-10 and Nehemiah 13 and the issue of dissolving marriages as well.

Jonker $(2016: 16,277)$ uses the heuristic lens of identity to study Chronicles as a single work. According to Jonker, the author (Chronicler) had the intention of contributing to the process of identity negotiation on behalf of the Levites in the late Persian period (cf. Jonker 2016:274). This 'identity negotiation' took place in close relationship with the 'sociohistorical context and literature formation' (Jonker 2016:vi, see also Jonker 2016:19). Jonker (2016:19) considers 'it important to work from a constructivist understanding of identity as identity negotiation'. There was a complex interplay between socio-historical circumstances, identity negotiation and the creating of literature.

Jonker avoids studying the social context on only one single level. Rather, he works with a context consisting of different interacting levels. During the late Persian period a layered context was constituted by an 'array of power relations' (Jonker 2016:vi). Based on the inner dynamics of the Chronicler text itself, he applies the results of postcolonial studies, utopian studies, social memory and social psychology. Jonker (2016:65) identifies 'four concurrent and overlapping levels of socio-historical existence' (Jonker 2016:277) in the last half of the fifth and the first half of the fourth century BCE. He formalises these levels into a fourfold programme of study on the social background of Chronicles. To study the interplay between the sociopolitical, socio-economic and socio-religious levels, Jonker follows a programme of investigating first the widest imperial context, next the narrower provincial context, then the local tribal context and lastly the cultic conditions in Jerusalem. This scheme he applies to each of the four literary units of Chronicles (1 Chr 1-9; 10-29; 2 Chr 1-9; 10-36).
Jonker points out some agreements as well as differences between Chronicles and Ezra-Nehemiah. The genealogies of returnees in Ezra 2, 8 and Nehemiah 7, 10, 11 and 12 are similar to those found in Chronicles defining the identity of the post-exilic community. Jonker (2016:20) remarks that it is 'particularly the narratives about the expulsion of foreign wives in Ezra 9-10 and Nehemiah 13 [that] make this issue very explicit'.

Jonker (2013 Logos Edition) also points out 'remarkable theological differences between Chronicles and EzraNehemiah'. There is a difference between the two works with regard to mixed marriages, Israel's earlier history, the contemporary position of the former northern kingdom in Samaria, the stipulation of who belongs to Israel, the notion of direct retribution, the role of cultic officials and the role of the Davidic kingdom. Like the authors of Ezra and Nehemiah, the authors of Chronicles selectively draw on Pentateuchal traditions, but they do so to a very different effect. When compared with each other, it becomes clear 'that the Jerusalem community contained many more voices than some have been willing to countenance' (Jonker 2016:196; see also Knoppers 2001:30).

Other studies of Chronicles can also be helpful to study the socio-historic background of Ezra-Nehemiah. Dyck (2002) compares Chronicles' type of identity with that found in Ezra-Nehemiah. His study was inter alia to 'examine whether Chronicles also reflects such an exclusivist view as that reflected in texts contemporaneous with it such as Ezra 10 and Nehemiah 13' (cf. Jonker 2016:17). Working with the concepts of identity and ethnicity, Dyck (2002:99) uses Kuper and Kuper's well-known definition of an ethnic group as those who share 'certain characteristics or combination of characteristic including language, religion, cultural tradition, and racial characteristics'. Dyck differentiates between vertical and lateral ethnie. Chronicles represents this last form of ethnicity. It shifted the restricted view of ethnicity in EzraNehemiah into a horizontal one to include all of Israel (an inclusive approach). According to Dyck, Jerusalem had a population of 1250-1500 in Persian times. Confined to a small area, Ezra-Nehemiah's ideology of identity was necessarily defined to be that of 'vertical ethnicity' (Dyck 2002:99) (an exclusive approach). The experience of exile 'had a profound affect on their self-understanding' (Dyck 2002:100). They aimed at maintaining "the sense of a distinctly "exilic" identity long after the return' (Dyck 2002:100). The further development of this exilic identity 'was determined by the nature of the relationship between the post-exilic community and its neighbours' (Dyck 2002:101). The conflict with other inhabitants with regard to possession of the land 'helped to crystallise the ethnic identity of the returnees' (Dyck 2002:101). The problem of intermarriage in the community is to be understood 'in light of the inherent weakness of vertical ethnic groups' (Dyck 2002:101). Vertical ethnicity usually confines a community's spatiality and economic relationship with other groups and increases their exclusivity. This contributed to the decision to dissolve some marriages. 
Knoppers $^{3}$ (2001) compares Chronicles' inclusive stance with the exclusive one in Ezra-Nehemiah. He studied the genealogy of Judah in Chronicles against the background of the Persian and early Hellenistic periods. Under the heading 'Exogamy, Ethnic Diversity, and Ezra-Nehemiah', Knoppers (2001:28) remarks that compared to the social and ethnic diversity Chronicles ascribes to Judah, Ezra-Nehemiah promotes exclusivity. Chronicles is inclusive. In Chronicles the 'phenomenon of mixed marriages is one means by which Judah expands and develops within the land' (Knoppers 2001:29). In Ezra 9:10-15 mixed marriages are a threat to the people. The authors of Ezra and Nehemiah 'endorse a very restricted notion of what constitutes Israel' (Knoppers 2001:28). What is more, the 'strictures of Ezra (9:1-10:44) and Nehemiah (13:23-28)' (Knoppers 2001:28) are not restricted to politics and religion only but have the much broader scope of also including measures of social nature, divorce, exclusion from the golah community, and the confiscation of property. The nations mentioned in Ezra 9:1 are only part of the 'standard pentateuchal list'. The lists in Genesis (15:19-21), Exodus $(3: 8,16 ; 33: 2 ; 34: 11)$, Deuteronomy (7:1-4 and 20:17) and Judges (3:5) are now expanded by Egyptians, Ammonites, Moabites and Edomites. Using 'ethnic labelling' Southwood (2011:46) draws up a 'cognitive map' (Southwood 2011:53) that enables one to understand power relations in Yehud. This extension is also 'critical to mandating the divorce and expulsion of wives not included in the earlier prohibitions' of Exodus and Deuteronomy (Knoppers 2001:29).

Studies of Chronicles, therefore, point out several sociohistoric aspects in Chronicles that are able to enhance our study of Ezra-Nehemiah. Different scholars used a plethora of social scientific methods to study various socio-economic factors in Ezra-Nehemiah as the background for the composition. Jonker's contribution is that these different aspects are to be studied interactively.

\section{Identity in Ezra-Nehemiah in the Persian and Hellenistic empire}

Scholars, as indicated already, differ on the time of EzraNehemiah's background. Siedlecki's (2008:263-276) proposal is that Ezra-Nehemiah in its final form comes from the early Hellenistic milieu. Heckl (2016:292) sees the clashes between the Ptolemeans and Seleucids of the late third century BCE as the background of the final form of Ezra-Nehemiah. Knoppers (2015:3) widens the scope to both the Achaemenid and Hellenistic periods. According to Eskenazi (2008:327) a Persian period can be accepted on the same grounds that Siedlecki and others used for their conclusion. The later Persian period is very broadly used as the background of Ezra-Nehemiah. Any refinement in this dating will of course affect the scholar's explanation of the dissolving events.

Various aspects are pointed out in the diachronic study of Ezra-Nehemiah. Some of them are discussed in what follows.

3.See also Min $(2002: 26-27)$.
Postcolonial studies indicate the interplay of empires and the resistance to its domination. Since the diminishing of Persian power by about 450 BCE, Yehud had exhibited some of the characteristics of a border or frontier as well as continuing its role as a colony (cf. Berquist 2007:195). It played its role as a colony of Persia but also resisted the empire. The interplay of dominance and resistance formed the social context for life in Yehud (Berquist 2007:195). As empires are constantly in a process of refashioning themselves (cf. Berquist 2007:196), the postcolonial society of Yehud adapted to circumstances by applying different forms of resistance. Eskenazi (1993: 77-78) indicates several possibilities for the resistance in Ezra-Nehemiah. Ezra-Nehemiah displays different social options within this context. Their opposition could have been, for instance, against some political measures by the Persian empire, such as an ethnical cleansing program. Those who read the Ezra-Nehemiah composition were, anyway, compromised to choose one specific position (cf. Berquist 2007:199).

A postcolonial society is usually pluralistic and could include 'multiple positions and positionalities that exist next to each other' (Berquist 2007:198). Knoppers (2015:3) indicates that within the one Persian empire there were 'multiple and overlapping relationships' among different groups spread over a wide area. There were 'ethnic minorities' (Knoppers 2015:4) living in different cities, all submissive to the same authority. They did have 'limited forms of self-organization and internal administration' (Knoppers 2015:4). There were also many Jews living in Judah, 'especially from the upper class' (cf. the nobles of Tekoa in Neh 3:5) (Albertz 2006:201). Some of the upper class fostered contacts with non-Jews. Doing 'macro-level analysis' (Johnson 2011:1) using the interdisciplinary methods of sociology, anthropology and critical literary analysis, Johnson sees identity forming within the confines of the Persian Empire as the basis for the marriage crisis. In Johnson's (2011:41) mind, any serious study of the mixed marriage phenomenon 'must consider its neighbors in Syria-Palestine and an understanding of the relationship between the satrapy "Beyond the River" and the other entities that composed the Persian Empire'. The crisis was indeed a 'multifaceted intermarriage dilemma' (Johnson 2011:1) triggered by the power control of Persia in the Achaemenid period.

The Yehud community had to reorganize and re-establish itself amid this postexilic communal confusion and chaos. To distinguish themselves from the ethnic Other, they used the language of purity and defilement. Although intermarriage seems to be the problem in Ezra, the real issue, according to Johnson, is the underlying threat of idolatry usually practiced by non-Israelites, causing contamination of the religious and cultural norms of the Yeduhites. For Blenkinsopp (2009:64), these women 'were not primarily, and certainly not exclusively, Gentiles'. They could have included 'indigenous Judeans and resident non-Judeans, including Ammonites, Moabites, Edomites, and women originating in Samaria and Philistia' (Blenkinsopp 2009:67). Eskenazi and Judd (1994:268) point out that 'the actual ethnic background' of the women in 
Ezra 9-10 is not specified. They therefore translate Ezra 9:1, along with the JPS Tanakh, as saying that these women are 'like' the Canaanites and other surrounding nations. It was only the Ammonites, Moabites and Egyptians mentioned in Ezra 9:1 who were still extant in the time Ezra-Nehemiah was written (cf. Frevel \& Conczorowki 2011:33 above). Of what is known regarding the demographic composition of Judah in the Persian period (cf. Ezkenazi \& Judd 1994:268), they could have been part of any of several groups of the time. Keeping socio-economic factors in mind, Eskenazi and Judd (1994:271) read the text in terms of 'land belonging to the Jewish province'.

Grabbe (1998:34) sees the reference to these nations as symbolic, referring to the nations Israel met when they first came to Canaan. Ezra places their problems 'squarely at the door of the inhabitants of the land with whom Israel should never had mixed' (Grabbe 1998:34). Johnson (2011:99) agrees and remarks that the 'foreign women in Ezra 9-10 symbolize impure foreign femininity, powerful enough to impart ritual havoc'. Snyman (2007:75) reads the passages in terms of 'exilic consciousness'. Due to their menstrual cycle, women are traditionally associated with impurity. The foreign women with their cultic impurity profane the holiness of the returning group and should be removed (cf. Snyman 2007:79). The main issue, according to Blenkinsopp (2009:67), 'is a theory of ritual ethnicity rather than simply what we would call religious affiliation'. In Johnson's mind the foreign women symbolize idolatry and therefore pollution. Within this context, Johnson (2011:24) concludes that the intermarriage debate underscores connections among the trauma of exile; the language of purity and pollution; ethnicity; and marriage'. This is what is depicted in Ezra 9-10.

Eskenazi and Judd use system theory and power-conflict theory to form a conceptual framework for the study of the phenomenon of intermarriage among ethnic groups. They believe that these sociological theories can be applied to all societies of all times (cf. Eskenazi \& Judd 1994:272). Having pointed out parallels between the mixed marriage problem in Ezra and the history of marriages in modern Israel, they come to the conclusion that Ezra brought a redefinition of who a Jew is. His view 'gained popular support among segments of the population' (Eskenazi \& Judd 1994:285), and this caused some legal reformulations and also some tensions in the community. This redefinition caused some women who were formerly accepted marriage partners to become outsiders and to be banished. Because of these developments under guidance of Ezra, they lost 'their legitimacy in the Jewish community' (Eskenazi \& Judd 1994:285).

Blenkinsopp (2009) also points out another aspect. In the Ancient Near East, marriage was a legal 'contractual arrangement'. The dissolving of any such marriage had serious economic consequences. However, in Ezra nothing is said with regard to these consequences. The same happens in Nehemiah. Nehemiah 13:23-27 renders 'legal authority for Nehemiah's rough treatment of Jews who had married women from the Philistine city of Ashdod' (Blenkinsopp 2009).

\section{Identity negotiation in Jerusalem}

Tollefson and Williamson's (1992:322) study of the book of Nehemiah shows that the book narrates a 'cultural revitalization process'. The returnees experienced a severe cultural dissonance between themselves and those who remained behind after the exile. A program for cultural transformation is then developed to form a group with shared values. A social-cultural change takes place, a new ethos blossoms up (Neh 9) and the Nehemiah group 'commit themselves to that new ethos' (Neh 10). In their reaction to the law, the people decided upon a 'radical change in their present ethos' (Tollefson \& Williamson 1992:337). Three factors played a role in this transformation: the presence of foreign wives; the lack of Sabbath observances; and the inadequate support for the temple (cf. Tollefson \& Williamson 1992:337-338). Tollefson and Williamson (1992:346) read the dissolving of the marriage in Nehemiah 13 therefore 'as part of the routinization of the cultransformation attested in ch. 10'.

These reforms had 'cultic significance' (Holmgreen 1987:67). For cultic reasons Nehemiah threw Tobiah out of the temple rooms. For the same reasons, Nehemiah addressed the problem of mixed marriages. According to Nehemiah, intermarriage was a sacrilege against God. He does not use the term 'seed' like Ezra, but he nevertheless touches on the sphere of 'holiness' (Albertz 2006:204). As the returnees formed a political and cultic society, the forced divorce and dismissal of children intended cessation of all cultic activity for them. For Nehemiah, the entire high priestly family had been defiled. They could no longer do their high priestly duty. 'Nehemiah's accusations are more radical than the legal restrictions applying to priests' (Albertz 2006:204). Those only prohibited marrying a harlot. 'Thus, Nehemiah adopted this marriage restriction for the high priest, used it specifically against alien women, and expanded its applicability to the entire high priestly family' (Albertz 2006:204). 'Thus, the expulsion of the polluted couple can best be understood as the first act in purifying the rest of the high priestly family' (Albertz 2006:204). Blenkinsopp (2009) summarises this whole action as 'ritually segregated, religiously homogeneous and autonomous polity' that dictated both Ezra and Nehemiah's actions from the start of the term of their respective offices and included a 'struggle against the priestly and lay aristocracy for control of the temple and its resources, spiritual and temporal'. His program was not merely directed at 'religious affiliation' but rather at 'ritual ethnicity' (Blenkinsopp 2009). For Albertz (2006:204), 'these ritual oppositions, the exclusion, were absolutely necessary'.

Ezra's idea of Judaism had direct effect for shaping group boundaries. The Ezra-Nehemiah narrative depicts a dynamic society who adopted 'ethnically differentiated communal boundaries as marks of purity' (Laird 2016:363) to avoid any recurrence of past transgression. Ezra 'explains his political conflict primarily in terms of ethnicity' (Albertz 2006:203). Nehemiah restricted membership of Judaism to those who belonged to the former Kingdom of Judah, including the offspring of Benjamin. In Nehemiah's exclusive policy, 'the 
term "Jew/Judean" automatically excluded all other descendants of former Israel, especially those of the Northern Kingdom' (Albertz 2006:203). In both Ezra's memoir and Nehemiah's memoir, purity language and ritual prescriptions are used to compel 'a community defined by ethnic, religious, and historical criteria' (Laird 2016:354).

With this as background Janzen reads the dissolving of marriages in terms of the rules for purity and the cleansing rituals in Leviticus 15 and 22. Janzen (2007) points out that no rationale is presented in Ezra 10 for the divorce and banishment of foreign women. Scholarly endeavours to solve this riddle can be grouped into three categories. First, this was the way the community tried to prevent the defection these women could cause. Secondly, it was done to define the ethnic identity of the group. Thirdly, these women disturbed the economic and political balance in Yehud. Janzen rejects apostasy, ethnic purity and economic-political reasons as issues, causing the avoidance of a clear rationale for this action. Janzen (2007:59) does not agree with the mutual opinion in these approaches 'that Ezra 9-10 obscures or omits the community's rationale for the expulsion'. He is of the opinion that the answer can indeed be found in the text itself.

Janzen (2007:62) indicates that the narrative depicts the nature of the women as the 'sources of pollution, ontologically opposite of "the holy seed" in the "holy place"". The men who married and allowed these women to live in the community are to be blamed. They allow them to be in a place where they should not have been. They are a danger for the group and they should therefore be separated from their husbands and be removed from society. To make this explanation graspable for modern readers, Janzen turns to anthropological theory. Ezra 9-10 manifests 'a society with strong group identity but weakening adherence to social morality' (Janzen 2007:63). Using the well-known theories of Douglas and Fenn on group forming and the role of boundaries, Janzen (2007) sees in the language used in Ezra 9-10 an indication of:

a community with strong external and weak internal boundaries that anxiously believes social deviancy is growing out of control: it wants to purify itself from the dangerous impurity of outside groups. (p. 67)

This transformation of ethos had economic aspects to it as well. In Jerusalem, there were different Yahwistic groups, some returning from the Eastern Diaspora (cf. Knoppers 2015:20). This was not developed in a social void, but in the context of a 'dynamic interaction of social, political, cultural, and economic forms of capital over time, in a particular place, among particular people' (Laird 2016:363). Their measures were related to the financial and political equilibrium in Yehud. Ezra and Nehemiah's programs ran wider than just the cult. According to Blenkinsopp (1991), the returnees applied the skills they developed in exile when they returned to Jerusalem. The economic situation in Yehud forced them to use these skills to get their hereditary property back from those who occupied the land during their absence (cf. Collins 2004: Logos edition). The returnees saw themselves as a pure and holy remnant whose character should not be contaminated in any way. During the returns of Sesbassar, Zerubbabel, Ezra and Nehemiah conflict arose between the returnees and those still living in the area. Among the inhabitants, some 'did not share Nehemiah's negative evaluation of the status of their province and opposed his political program to a greater or lesser degree' (Albertz 2006:203). Collins (2004) refers to Malachi 2:10-16 as an example of the contemporary 'protest against Ezra's enforced policy'.

Laird's (2016:345) idea quoted above, that Ezra-Nehemiah was composed by an array of authors at different times, asks for closer analysis of these different phases. For this purpose, she uses the theories of Weber on the interaction of social agents and of Bourdieu on 'social space, symbolic language, and the field of production' (Laird 2016:37). Using their methods will enhance a better understanding of a social world in which minority groups implemented excommunication. Application of the methods of Weber and Bourdieu 'may also allow us to understand more fully the painful texts that advocate the exclusion of others, the divorce of wives, and the expulsion of them with their children' (Laird 2016:38).

When one sides with the view that Ezra was added later on, Nehemiah should be read as representing an older trajectory and Ezra 1-6 the youngest phase. In each of the redactional phases of Ezra-Nehemiah, different plans or actions were performed to attain the goals of the authors in the different changing social contexts. In the older Nehemiah memoir with its heroic tale of Nehemiah, the main tendency was 'removing the shame of destruction' (Laird 2016:359). In the older Nehemiah, unspecified and stereotyped foreigners (people of the land) are introduced as adversaries to the community. In Nehemiah 13:26-27, foreignness is linked to the divine punishment mentioned in Nehemiah's prayer. The members of his society are reprimanded to ask for forgiveness of their transgression by separating from the foreign women to whom some of them are married. Nehemiah 13:28 narrates how Nehemiah chased away the son of Joiada, son of the high priest Eliashib in Jerusalem. Josephus (Antiquities XI, 306-312) describes how Manasse, the brother of the high priest Yaddua, left Jerusalem because of Nehemiah's rules. Sanballath, the governor of Samaria (his father-in-law), made him high priest of the new temple erected on Mount Gerizim at the end of the 5th century BCE. This indicates the type of conflict there was. In Ezra 7-10 and Nehemiah 8 the quest was how to find an exclusive identity for the re-migrated exiles in Yehud. They were grounded in exilic practices like Torah study 'and signing covenants to maintain practices of boundary maintenance such as Sabbath keeping and endogamous marriage contracts' (Laird 2016). All of these had to become daily practice in Yehud. In the newest section of Ezra 1-6 the main purpose was to establish the temple as the central component of the community in their daily life (cf. Laird 2016:359).

The 'changing circumstances were met with changing tactics and were accompanied by a move toward greater exclusionary practices' (Laird 2016:357). The group had to be reformed 
into an 'instituted group' (Laird 2016:357). The cultural ethos of a group of returnees is gradually metamorphosed here 'into a religious ethical requirement for the entire community' (Laird 2016:360). Although the growing demands of the Persian empire are met, the Ezra-Nehemiah group are 'clearly exclusionary in terms of ethnicity' (Laird 2016:360). With a new 'rigid definition of the community' (Laird 2016:358), the leaders used all they could to remake the nature of the exilic community. For this purpose, several actions were needed, like giving tithes to the temple, writing off interest on loans for co-members, enforcing 'social boundaries through exclusionary measures (sacrificing wives and children, ejecting those labelled as foreign)' (Laird 2016:359) and sacrificing their time and money to the erection of public buildings like the walls and temple.

Contributing to the evolving construction of a 'community with an exclusive and exilic character' (Laird 2016:348), new marital arrangements were made in Ezra 6-10. These drastic steps were taken in the face of resistance, perils to forming an exclusive identity and growing conflict with other inhabitants in Yehud. Committed to religious purity, the Ezra group excommunicated women tagged in terms of the ethnic parameters of the group. According to Johnson (2011:99), 'the predominant motivating force in Ezra 9-10 had nothing to do with race per se'. Although Ezra 9-10 depicts intermarriage as a religious and not an economic issue, the real issue is 'the fierce struggle over limited resources and few leadership positions' (Johnson 2011:54). This should be explained in terms of the 'pattern of Othering in antiquity'. When a group experienced 'loss of economic and political control' (Johnson 2011:78), the group projected its xenophobia 'onto the Other, thereby depicting or stereotyping the Other as having lost the control that the group itself has suffered' (Johnson 2011:78). When read from an anthropological, narratological and ideological perspective, it is clear for Johnson (2011:94) that Ezra 9-10 includes 'gender, race, religion, sexuality and social class, all as parts of an interactive multidimensional dynamic at work in the text'. He comes to the conclusion that the 'ostensible message of Ezra 9-10 is the confession and conversion of the unfaithful people who had intermarried but through repentance were united into one God-fearing ethnic entity' (Johnson 2011:94).

Southwood (2011:46) uses the method of 'ethnic labelling' to study Ezra 9-10. This method enables her to identify those who controlled 'self-designations and classifications of Others' (Southwood 2011:46). A 'cognitive map' (Southwood 2011:53) can thereby be drawn of the 'possible power structures within post-exilic Yehud' (Southwood 2011:58). By using the antique lists of nations to be avoided in Genesis, Exodus, Deuteronomy and Judges, non-violable ethnic boundaries are demarcated between Israel (the holy seed, the returning exiles, the remnant) and the homogenized picture of those outside the boundaries' (Southwood 2011:54). Whoever crosses this holiness boundary will find himself in a lethal 'between and betwixt' (Southwood 2011:55) situation. That is the crisis that intermarriages with foreign women brought along in the exilic community. In this way, the concept of holiness is applied to ethnicity. Holiness in Ezra 'is used in an exclusionary, polemical sense, and it is through this that ethnicity is communicated in the guise of ritualized religious regulation' (Southwood 2011:56). The image of seed is used here in a 'pseudo-legal argument' (Southwood 2011:58) for the 'powerful validation of endogamy' (Southwood 2011:58).

Blenkinsopp (2009:67) correctly points out that Ezra 9-10 is anomalous, reporting 'a conflict of interpretations in which we have access to only one side of the debate'. Nehemiah's actions had a political aspect 'which can be described telegrammatically as ritual ethnicity' (Blenkinsopp 2009:143). He applied ritual values to politics. His struggle against the priests for control of the temple was dictated right from the beginning by the 'goal of a ritually segregated, religiously homogeneous and autonomous polity' (Blenkinsopp 2009:143).

Adams (2014) proposes a 'more economic reading' of Ezra 9-10. He sees Ezra's reforms as uniting affluence and assets into one unique identity. Usually in endogamic marriages 'economic motivations are a central factor' (Adams 2014). Ezra applies this to his use of earlier traditions (as found in Dtnm 7 and 23 and Lv 18:24-30). He understands every person who is not part of the returnees to be profane. Both marriage partners should be from the returning exiles. In this way, Ezra creates a binary opposition between the holy community and the profane outsiders. The demographics of Judah with its different ethnic groups are closely related to ancestral property rights. Ezra's aversion to intermarriage between returnees and non-returnees was intended to assure authority and financial control for his group. For Ezra, 'Foreign wives could threaten the landholding rites of returning male exiles' (Adams 2014:27). Adams sees the situation in Nehemiah 13 as slightly different. Nehemiah 'bemoans the corruption of the priestly aristocracy and, by extension, the sanctity of the temple'. Here intermarriage would have endangered the status of people.

To summarise the section on diachronic analysis: a text is always part of the social context in which it was produced. The studies of Jonker, Dyck and Knoppers of Chronicles can be helpful to study Ezra-Nehemiah's socio-historic background. Methodically, Jonker's (2016) proposal of integrating social disciplines with study identity forming in Chronicles is important. The text should be investigated on several social-historical levels. In Ezra-Nehemiah many voices are speaking from a historical context. In comparison with Chronicles' lateral ethnic stance on including others in Israel, Dyck (2002) indicates that Ezra-Nehemiah shows an exclusivist, vertical ethnicity typical of groups living in a confined space vying with others sharing the same area. This was the reason for Ezra-Nehemiah's dissolving of intermarriages. Knoppers (2001) indicates that the restricted identity definition of Israel in Ezra-Nehemiah embraces much more than mere politics and religion. What lies behind the dissolving of marriages in Ezra-Nehemiah included aspects of a general social nature, matrimonial rules and confiscation of property. 
Within the confines of the Persian (or Hellenistic) empire, Ezra-Nehemiah represents a form of resistance. Living among an array of different groups, the Yehud community had to establish themselves as an independent group. The women who had to be divorced were not necessarily Gentiles. They were rather those identified in some way or another with idolatry and sacral impurity, presenting a threat to the ritual ethnicity of the Yehud group. The self-definition of this group excluded others who did not comply with their criteria. The legal requirements for divorce are not mentioned in Ezra-Nehemiah. That sustains the view that it was first and foremost the effort of a religious group in Ezra-Nehemiah that advanced a unique identity among the different groups in the empire.

Ezra-Nehemiah reflects a transformation with cultic consequences. The returnees advanced a new ethos and ritual ethnicity. The group's idea of purity excluded marriages with women who did not comply with their criteria for membership. Going wider than just the cult, the returnees established group boundaries and tried to establish themselves as leaders in the economic arena as well. Ranging from Nehemiah's earlier actions to those of Ezra later on, changing incremental tactics were applied to ameliorate the group's exclusiveness. This included drastic marital arrangements to purify the group from outsiders. In this way, a binary opposition was created between the holy community and the so-called profane outsiders.

\section{Conclusion}

The dissolving of marriages in Ezra 10:1-44 and Nehemiah 13:23-31 is strange to modern thinking. Following Jonker's (2016:64) 'interdisciplinary multidimensional approach' to Chronicles, this article proposes that a restricted heuristic approach following only one avenue of investigation is no longer adequate for understanding these passages in the Bible. The investigation above shows that they should be studied on at least three levels: synchronically in their literary context, synchronic-diachronically according to the hermeneutical literary growth of the books during a sequence of events, and diachronically against the probable social background of this terminating of marriages.

A synchronic analysis indicates that it should be understood in terms of the new community's enterprise to be holy. The narration indicates a closed community restricted to returnees from the golah. Their application of cultic rules of purity forced them to declare marriages to women who did not comply with this criterion to be unlawful.

Intertextuality between these two passages, as well as with literature from the Torah, invites us to read them as part of a growing composition. Scholars disagree on the sequence of this process - a flaw in this type of study. Some follow the order of the Masoretic text, and some see Ezra as the final point in the redactional growth of Ezra-Nehemiah. However, they all agree that a process of refining a new identity occurred. The Torah was used in a particularistic way to close down the ranks of the community, excommunicating all those who presented a threat to the claimed purity of the group. Spouses of foreign ancestry represented this threat and were to be sent away.

Read against the multidimensional background of their time, the passages represent many voices. Within the context of the Persian empire, women who were synonymous with idolatry symbolized a threat to sacral purity. To maintain their unique identity among the different groups in the empire, drastic steps were taken by the Ezra-Nehemiah group to end some of these marriages. This manoeuvre was part of a larger attempt of the group to establish themselves as leaders in the community of Jerusalem. This embraced all parts of social life, theologically, economically and culturally.

These three approaches prove that these texts are to be interpreted within a much larger scope of investigation than was applied up till now. This article corroborates my proposal of a multilevel investigation into biblical texts. However, it also confronts us with the phenomenon of a biblical canon consisting of contradictory viewpoints on identity. Read along with the narrative of Esther, propagating Jewish exclusiveness, Ezra-Nehemiah stands in contrast to the inclusive views held in books like Ruth, Jonah and Third Isaiah.

\section{Acknowledgements Competing interests}

The author declares that he has no financial or personal relationships which may have inappropriately influenced him in writing this article.

\section{References}

Adams, S.L., 2014, Social and economic life in Second Temple Judea, Westminster John Knox Press, Louisville, KY.

Albertz, R., 2006, 'Purity strategies and political interests in the policy of Nehemiah', in S. Gitin, J.E. Wright \& J.P. Dessel (eds.), Confronting the past: Archaeological and historical essays on Ancient Israel in honor of William G. Dever, pp. 199-206, Eisenbrauns, Winona Lake, IN.

Bautsch, R., 2007, 'Intertextuality in the Persian period', in J.L Berquist (ed.), Approaching Yehud. New approaches to the study of the Persian period, pp. 25-35, Society of Biblical Literature, Atlanta, GA.

Berquist, J.L., 2007, 'Psalms, postcolonialism, and the construction of the Self', in J.L Berquist (ed.), Approaching Yehud. New approaches to the study of the Persian period, pp. 195-202, Society of Biblical Literature, Atlanta, GA.

Blenkinsopp, J., 1991, 'Temple and society in Achaemenid Judah', in P.R. Davies (ed.), Second temple studies I. Persian period, JSOTSup 117, pp. 22-53, JSOT Press, Sheffield.

Blenkinsopp, J., 2009, Judaism: The first phase. The place of Ezra and Nehemiah in the origins of Judaism, Logos edn., Eerdmans, Grand Rapids. MI.

Boyarin, D., 1990, Intertextuality and the reading of Midrash, Indiana University Press, Bloomington, IN

Collins, J.J., 2004, Introduction to the Hebrew Bible: An inductive reading of the Old Testament, Logos edn., Fortress Press, Minneapolis, MN.

Clauss, J., 2011, 'Understanding the mixed marriages of Ezra-Nehemiah in the light of temple-building and the book's concept of Jerusalem', in C. Frevel (ed.), Mixed marriages. Intermarriage and group identity in the second temple period, pp. 109-131, T\&T Clark, London.

Dyck, J.E., 2002, 'The ideology of identity in chronicles', in M.G. Brett (ed.), Ethnicity and the bible, pp. 89-116, Brill Academic Publishers, Boston, MA.

Eskenazi, T.C., 1988, In an age of prose: A literary approach to Ezra-Nehemiah, SBL Monograph Series 36, Scholars Press, Atlanta, GA.

Eskenazi, T.C., 1993, 'Current perspectives on Ezra-Nehemiah and the Persian period', Currents in Research: Biblical Studies 1, 59-86. 
Eskenazi, T.C., 2008, 'Unity and disunity in Ezra-Nehemiah: Responses and reflections', in M.J. Boda \& P.L. Redditt (eds.), Unity and disunity in Ezra-Nehemiah, pp. 315-328, Hebrew Bible Monographs 17, Sheffield Phoenix Press, Sheffield.

Eskenazi, T.C. \& Judd, E.P., 1994, 'Marriage to a stranger in Ezra 9-10', in T.C. Eskenazi \& K.H. Richards (eds.), Second temple studies 2: Temple and community in the Persian period, JSOTSup 175, pp. 266-285, Sheffield Academic Press, Sheffield.

Fishbane, M., 1985, Biblical interpretation in ancient Israel, Clarendon, Oxford.

Fisk, B.N., 2001, Do you not remember? Scripture, story and exegesis in the rewritten bible of Pseudo-Philo, Journal for the Study of the Pseudepigrapha, suppl ser 37, Sheffield Academic, Sheffield.

Frevel, C. \& Conczorowski, B.J., 2011, 'Deepennig the water: First steps to a diachronic approach on intermarriage in the Hebrew Bible', in C. Frevel (ed.), Mixed marriages, intermarriage and group identity in the Second Temple period, pp. 15-45, T\&T Clark, London.

Giffone, B.D., 2014, Sit at my right hand: The Chronicler's portrait of the tribe of Benjamin in the social context of Yehud, Dissertation presented for the degree of Doctor of Philosophy at the University of Stellenbosch.

Grabbe, L., 1998, Ezra-Nehemiah, Routledge, London.

Heckl, R., 2016, Neuanfang und Kontinuität in Jerusalem. Studien zu den hermeneutischen strategien im Ezra-Nehemia-Buch, Mohr Siebeck, Tübingen.

Holmgreen, F.C., 1987, Israel alive again: A commentary on the books of EzraNehemiah, Handsell Press, Edinburgh.

Janzen, D., 2007, 'Scholars, witches, ideologues, and what the text said: Ezra 9-10 and its interpretation', in J.L. Berquist (ed.), Approaching Yehud. New approaches to the study of the Persian period, pp. 49-69, Society of Biblical Literature, Atlanta, GA.

Japhet, S., 1994, 'Composition and chronology in the book of Ezra-Nehemiah', in T.C. Eskenazi \& K.H. Richards (eds.), Second temple studies: Volume 2: Temple and community in the Persian period, pp. 189-216, Sheffield Academic Press, Sheffield.

Johnson, W.M., 2011, The holy seed has been defiled. The interethnic marriage dilemma in Ezra 9-10, Hebrew Bible Monographs 33, Phoenix Press, Sheffield.

Jonker, L.C., 2013, 1 \& 2 Chronicles, Baker Books, Logos edn., Grand Rapids, MI.

Jonker, L.C., 2016, Defining all-Israel in Chronicles. Multi-levelled identity negotiation in late Persian-period Yehud, Mohr Siebeck, Tübingen.
Knoppers, G.N., 2001, 'Intermarriage, social complexity, and ethnic diversity in the genealogy of Judah', Journal of Biblical Literature 120(1), 15-30. https://doi. org/10.2307/3268591

Knoppers, G.N., 2015, 'The construction of Judean diasporic identity in EzraNehemiah', Journal of Hebrew Scriptures 15, Article 3, 1-29. https://doi.org/ 10.5508/jhs.2015.v15.a3

Laird, D., 2016, Negotiating power in Ezra-Nehemiah, SBL Press, Atlanta, GA

Min, K.-J., 2002, 'The Levitical authorship of Ezra-Nehemiah', Durham thesis, Durham University, Durham, viewed n.d., from http://etheses.dur.ac.uk/4230/

Pakkala, J., 2011, 'Intermarriage and group identity in the Ezra tradition (Ezra 7-10 and Nehemiah 8)', in C. Frevel (ed.), Mixed marriages, intermarriage and group identity in the Second Temple period, pp. 78-88, T\&T Clark, London.

Siedlecki, A., 2008, 'Contextualization of Ezra-Nehemiah', in M.J. Boda \& P.L. Redditt (eds.), Unity and disunity in Ezra-Nehemiah, Hebrew Bible Monographs 17, pp. 263-276, Sheffield Phoenix Press, Sheffield.

Snyman, G., 2007, 'Collective memory and coloniality of being as a hermeneutical framework: A partialised reading of Ezra-Nehemiah', Old Testament Essays 20(1), 53-83.

Southwood, K., 2011, 'An ethnic affair? Ezra's intermarriage crisis against a context of "Self-Ascription" and "Ascription of Others"', in C. Frevel (ed.), Mixed marriages, intermarriage and group identity in the second temple period, pp. 46-59, T\& Clark, London.

Tollefson, K.D. \& Williamson, H.G.M., 1992, 'Nehemiah as cultural revitalization: An anthropological perspective', in J.C. Exum (ed.), The historical books. A Sheffield reader, pp. 322-348, Sheffield Academic Press, Sheffield.

Throntveit, M.A., 1992, Ezra-Nehemiah, John Knox, Louisville, KY.

VanderKam, J., 1992, 'Ezra-Nehemiah or Ezra and Nehemiah?', in E. Ulrich, J.W. Wright \& R.P. Carroll (eds.), Priests, prophets and scribes: Essays on the formation and heritage of Second Temple Judaism in honour of Joseph Blenkinsopp, pp. 55-75, JSOTSup 149, JSOT Press, Sheffield.

Van Wyk, W.C., 2001, 'The nature of the conflict in Ezra-Nehemiah', Hervormde Teologiese Studies 57(3\&4), 1254-1263.

Williamson, H.G.M., 1985, Ezra, Nehemiah, Word Biblical Commentary, vol. 16, Logos edn., Word Books, Dallas, TX.

Williamson, H.G.M., 1987, Ezra and Nehemiah, Old Testament Guides, Sheffield Academic Press, Sheffield. 